\title{
Quantitative evaluation of microleakage in class V cavities using one-bottle and self-etching adhesive systems
}

\section{Avaliação quantitativa da microinfiltração em cavidades classe $V$ utilizando sistemas adesivos de frasco único ou autocondicionante}

\author{
Fabiana Mantovani Gomes França* \\ Flávio Henrique Baggio Aguiar* \\ Alex José Souza dos Santos* \\ José Roberto Lovadino**
}

\begin{abstract}
The aim of this in vitro study was to evaluate quantitatively the microleakage in class $\mathrm{V}$ cavities restored with one-bottle and self-etching adhesive systems with and without previous acid etching. Two one-bottle adhesive systems (Single Bond and Prime $\&$ Bond 2.1) and one self-etching adhesive system (Clearfil Mega Bond) were used in this study. One hundred and twenty sound human premolar teeth were randomly divided into 6 groups, and 20 class $\mathrm{V}$ restorations were prepared in the root dentin to test each bonding system. Each bonding system was used with and without acid etching. Specimens were prepared, dyed with $2 \%$ methylene blue, sectioned, triturated, and evaluated with an absorbance spectrophotometer test in order to quantify the infiltrated dye. Results were statistically evaluated by ANOVA and Tukey-Kramer test. No statistically significant differences were found among the adhesive systems when no etching agent was used. However, the Single Bond adhesive system showed statistically significant lower microleakage means than Clearfil Mega Bond and Prime $\&$ Bond 2.1 when $37 \%$ phosphoric acid was used. Single Bond and Clearfil Mega Bond adhesive systems presented similar behavior when the manufacturers' instructions were followed.
\end{abstract}

DESCRIPTORS: Dentin-bonding agents; Dental leakage; Composite resins.

\begin{abstract}
RESUMO: O objetivo deste estudo in vitro foi avaliar quantitativamente a microinfiltração em cavidades classe V restauradas com a utilização de sistemas adesivos de frasco único e autocondicionante com e sem a realização de condicionamento ácido prévio. Dois sistemas adesivos de frasco único, Single Bond e Prime $\&$ Bond 2.1, e um sistema adesivo autocondicionante, Clearfil Mega Bond, foram utilizados. Cento e vinte pré-molares humanos hígidos foram divididos em seis grupos, e vinte restaurações classe $\mathrm{V}$ foram preparadas na dentina radicular para avaliar cada sistema adesivo. Cada sistema adesivo foi utilizado com e sem condicionamento ácido. Os espécimes foram preparados, corados com azul de metileno a $2 \%$, seccionados, triturados e avaliados em espectrofotometria para quantificar o corante infiltrado. Os dados foram submetidos a ANOVA e ao teste de Tukey-Kramer. Nenhuma diferença estatística significativa foi encontrada entre os sistemas adesivos quando o condicionamento ácido não foi utilizado. No entanto, o sistema adesivo Single Bond demonstrou menores médias de microinfiltração comparadas às médias dos sistemas adesivos Clearfil Mega Bond e Prime \& Bond 2.1 quando o condicionamento com ácido fosfórico a $37 \%$ foi utilizado. Os sistemas adesivos Single Bond e Clearfil Mega Bond demonstraram o mesmo comportamento quando as recomendações do fabricante foram seguidas.

DESCRITORES: Adesivos dentinários; Infiltração dentária; Resinas compostas.
\end{abstract}

\section{INTRODUCTION}

The mechanism of bonding to dentin is defined as micromechanical, where the adhesive resin penetrates into open dentinal tubules and into the intertubular demineralized dentin matrix ${ }^{3,27,28}$. The initial conditioning of the dentin results in demin- eralization, and dentin is subsequently reinforced with cured resin materials ${ }^{14,29}$.

In order to simplify and facilitate the bonding procedures and to reduce the time needed for application, "single-bottle" adhesive systems

\footnotetext{
*PhDs, Research Assistants; **PhD, Professor and Chairman - Department of Restorative Dentistry, School of Dentistry of Piracicaba, State University of Campinas.
} 
França FMG, Aguiar FHB, Santos AJS, Lovadino JR. Quantitative evaluation of microleakage in class V cavities using one-bottle and self-etching adhesive systems. Braz Oral Res 2004;18(3):253-9.

have been developed ${ }^{25,28}$. These systems combine the primer and the adhesive resin in one bottle. However, these one-bottle systems also require a prior conditioning treatment of the dental hard tissues.

Another group of adhesive systems called "self-etching" were also developed in an attempt to simplify the application procedure ${ }^{7,28}$. Theoretically, no gaps would be left between the primed dentin and the demineralization surface of the underlying dentin matrix in an adhesive system which simultaneously demineralizes dentin and fills it with monomers which are then polymerized in situ ${ }^{17,30}$.

The most common methods for evaluating bonding of restorative materials to tooth substrates measure the bond strength at the tooth restorative interface by testing the marginal seal of restorations in extracted teeth. The ideal adhesive restorative material would produce high bond strength values with no microleakage ${ }^{8}$.

Microleakage is cited as the responsible factor for the development of recurrent caries, marginal staining and postoperative sensitivity, which are caused by marginal infiltration of oral fluids, bacteria, molecules or ions at the interface of teeth and restorative materials ${ }^{10,13}$. There is little published data available comparing one-bottle and self-etching adhesive systems.

Some authors found that the acidity of singlebottle adhesives may re-etch the demineralized dentin $^{22}$. Barkmeier et al. ${ }^{1}$ (1999) found that an acetone-based adhesive system acted as a "selfetching" adhesive due to the acidity of its monomer PENTA (dipentaerythritol pentaacrylate). For this reason, we intend to evaluate these "single-bottle" and "self-etching" adhesive systems with and without acid etching the dentin.

The aim of this in vitro study was to quantitatively evaluate microleakage by means of an spectrophotometric analysis in class $\mathrm{V}$ cavities restored with one-bottle and self-etching adhesive systems with and without acid etching the dentin.

\section{MATERIALS AND METHODS}

One hundred and twenty human permanent mandibular and maxillary single-rooted premolars were used in this study. After extraction, teeth were cleaned of gross debris, polished and examined under a light microscope (Carl Zeiss, Gottingen, Germany) (4 X) in order to discard damaged teeth. All teeth were stored in distilled water at $5^{\circ} \mathrm{C}$ for three months prior to testing. The root apices were removed with a diamond disc (KG Sorensen Ind. e Com. Ltda., Barueri, SP, Brazil) and sealed with composite resin (Z250, 3M/ESPE, St. Paul, MN, USA) and a cyanoacrylate adhesive (Superbonder, Henkel Loctite Adhesives Ltd., Itapevi, SP, Brazil).

Cylindrical class V cavities of $1.85 \pm 0.05 \mathrm{~mm}$ in diameter and $1.5 \mathrm{~mm}$ in depth were prepared $4.0 \mathrm{~mm}$ below the cemento-enamel junction at the buccal surface with a special diamond bur which had the cavities' dimensions (KG Sorensen Ind. e Com. Ltda., Barueri, SP, Brazil). The bur was used at high speed and with adequate water cooling. Each diamond bur was replaced after five preparations. After preparation, the teeth were randomly assigned into six test groups $(\mathrm{n}=20)$. The cavities were restored with three different adhesive systems: Single Bond (3M/ESPE, St. Paul, MN, USA), Prime \& Bond 2.1 (Dentsply De Trey, Konstanz, Germany) and Clearfil Mega Bond (Kuraray Co., Osaka, Japan); compositions, manufacturer's instructions and batch numbers are shown in Table 1.

All adhesive systems were used with and without previous acid etching. The adhesives Single Bond and Prime $\&$ Bond 2.1 were used with the etching agent suggested by the manufacturer and Clearfil Mega Bond was used with 35\% Scotchbond phosphoric acid gel (3M/ESPE, St. Paul, MN, USA) for 15 seconds prior to the adhesive application. All cavities were bulk filled with a microhybrid composite resin, Z250 (3M/ESPE, St. Paul, MN, USA) and light cured for 20 seconds with Degulux Soft-Start curing light unit (Degussa, Hüls AG, Hanau, Germany) with a constant intensity of $620 \mathrm{~mW} / \mathrm{cm}^{2}$. All the restorations were made by the same investigator.

The restored teeth were subjected to 3,000 thermal cycles of 60 seconds between $5^{\circ} \mathrm{C}$ and $55^{\circ} \mathrm{C}$, with a dwell time of 15 seconds. After cycling, the whole tooth surface except a $1 \mathrm{~mm}$ window around the restoration was covered with two coats of nail varnish (Risque, Niasi, SP, Brazil), and teeth were immersed in $2 \%$ methylene blue solution (Merck, Darmstadt, Germany) for 12 hours at $37^{\circ} \mathrm{C}$. The samples were rinsed in tap water and dried afterwards. Specimens were cut with diamond discs and sections of the root $(5 \times 5 \mathrm{~mm})$ including the restorations were removed. The nail varnish and the superficial stain were removed from each specimen with a graded series of aluminum oxide discs (Sof Lex, 3M/ESPE, St. Paul, 
França FMG, Aguiar FHB, Santos AJS, Lovadino JR. Quantitative evaluation of microleakage in class V cavities using one-bottle and self-etching adhesive systems. Braz Oral Res 2004;18(3):253-9.

TABLE 1 - Adhesive system composition, manufacturers' instructions, $\mathrm{pH}$ and batch number.

\begin{tabular}{|c|c|c|c|c|c|c|}
\hline \multicolumn{2}{|c|}{ Adhesive } & \multirow{2}{*}{$\begin{array}{l}\text { Components } \\
\text { MDP, HEMA, hydrophilic } \\
\text { dimethacrylate, CQ, N,N-diethanol } \\
\text { p-toluidine, water. }\end{array}$} & \multirow{2}{*}{\begin{tabular}{l}
\multicolumn{1}{c|}{ Bonding steps } \\
Gently air dry, apply primer, 20 \\
seconds light curing.
\end{tabular}} & \multirow[b]{3}{*}{2.0} & \multicolumn{2}{|l|}{ Batch } \\
\hline \multirow{2}{*}{ 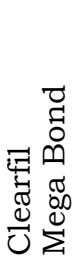 } & \multirow{2}{*}{\begin{tabular}{|l} 
Primer \\
Bond
\end{tabular}} & & & & 00103A & in \\
\hline & & $\begin{array}{l}\text { MDP, BisGMA, HEMA, hydrophobic } \\
\text { dimethacrylate, CQ, N,N-diethanol } \\
\text { p-toluidine, silanated colloidal } \\
\text { silica. }\end{array}$ & $\begin{array}{l}\text { Apply adhesive, } 10 \text { seconds } \\
\text { light curing. }\end{array}$ & & 00033A & \\
\hline \multicolumn{2}{|c|}{ Single Bond } & $\begin{array}{l}\text { - } 35 \% \text { phosphoric acid } \\
\text { - HEMA, BisGMA, PAA, ethanol and } \\
\text { water. }\end{array}$ & $\begin{array}{l}\text { Acid etch for } 15 \text { seconds, rinse } \\
\text { for } 15 \text { seconds, gently air dry. } \\
\text { Apply one coat of adhesive, wait } \\
\text { for } 10 \text { seconds, apply another } \\
\text { coat of adhesive, gently air dry } \\
\text { and light cure for } 10 \text { seconds. }\end{array}$ & \pm 5.0 & \multicolumn{2}{|l|}{ 9DD } \\
\hline \multicolumn{2}{|c|}{$\begin{array}{l}\text { Prime \& Bond } \\
2.1\end{array}$} & $\begin{array}{l}\text { - } 37 \% \text { phosphoric acid } \\
\text { - PENTA, elastomeric dimethacrylate } \\
\text { resins, cetylamine hydrofluoride, } \\
\text { CQ and acetone. }\end{array}$ & $\begin{array}{l}\text { Acid etch for } 15 \text { seconds, rinse } \\
\text { for } 15 \text { seconds, gently air dry. } \\
\text { Apply one coat of adhesive, wait } \\
\text { for } 30 \text { seconds, apply another } \\
\text { coat of adhesive, gently air dry } \\
\text { and light cure for } 10 \text { seconds. }\end{array}$ & \pm 1.7 & \multicolumn{2}{|c|}{50132} \\
\hline
\end{tabular}

*pH provided by manufacturers. Abbreviations: BisGMA: bisphenol-glycidyl methacrylate; HEMA: 2-hydroxyethylmethacrylate; MDP: 10-methacryloyloxy methacrylate; PENTA: dipentaerythritol pentaacrylate; CQ: camphorquinone; PAA: polyalkenoic acid copolymer.

MN, USA) in order to remove possible superficial dye absorption by the restorative material.

Each specimen was weighed and ground into powder in a mill for hard tissues (Marconi Equip. Ltda., Piracicaba, SP, Brazil). The powder of each specimen was weighed again and if the difference between the initial and final weigh was greater than $10 \%$ the sample would be discarded. The powder of each sample was individually immersed in a glass tube containing $4 \mathrm{ml}$ of absolute alcohol (Merck, Darmstadt, Germany), for 24 hours, in order to recover the methylene blue. After this procedure, the solutions were centrifuged (Tomy, IC 15NA, Tomy Ind., Tokyo, Japan) at 3,000 rpm for $3 \mathrm{~min}$. The supernatant was analyzed using an absorbance spectrophotometer (Beckman DU 65 - Instruments, Inc., Fullerton, CA, USA) adjusted with a wavelength of $565 \mathrm{~nm}$. In order to determine the absorbance, the spectrophotometer was adjusted with an appropriate wavelength for the methylene blue, corresponding to the maximum absorbency for the dye. Standard solutions of methylene blue in $1 \mathrm{ml}$ of absolute alcohol were prepared, containing from 0 to $4 \mu \mathrm{g}$ of dye $/ \mathrm{ml}$. The absorbance of the standard solutions were determined at wavelengths ranging from 500 to $700 \mathrm{~nm}$, and the best results were obtained at $565 \mathrm{~nm}$. Prior to determining the absorbance of experimental solutions at $565 \mathrm{~nm}$, the coefficient (r) between dye concentration and absorbance of the standard solutions was calculated, and an $r$ value of 0.9998 was obtained. To estimate the dye concentration on the experimental samples, a linear regression was obtained. The regression equation is expressed as: $\mathrm{y}=0.2714 \mathrm{x}-0.0071$, where $\mathrm{y}$ is the absorbance and $\mathrm{x}$ is the dye concentration. The microleakage of each specimen was expressed as $\mu \mathrm{g}$ of dye $/ \mathrm{ml}$, with lower values indicating lower microleakage. Data were statistically analyzed by two-way ANOVA and Tukey-Kramer test.

\section{RESULTS}

The results of the analysis of variance revealed significant differences in the microleakage means based on two independent variables $(p<0.05)$. The quantitative microleakage was not significantly different among groups for the acid etching factor $(p=0.1462)$, but it was significantly different for the adhesive systems $(p=0.0001)$, and for the interaction between adhesive systems $v$ s. etching $(p=0.0208)$. Tukey-Kramer test was used to compare the microleakage means among the groups $(\mathrm{p}<0.05)$. Results are shown in Tables 2 and 3 and Graphs 1 and 2. No significant differences were found among groups when no etching agent was used before the application of the adhesive systems. When teeth were previously acid etched, 
França FMG, Aguiar FHB, Santos AJS, Lovadino JR. Quantitative evaluation of microleakage in class V cavities using one-bottle and self-etching adhesive systems. Braz Oral Res 2004;18(3):253-9.

TABLE 2 - Means and standard deviations (SD) of dye concentration $(\mu \mathrm{g} / \mathrm{ml})$ for the adhesive systems used without previous acid etching.

\begin{tabular}{l|c}
\hline \multicolumn{1}{c|}{ Adhesive systems } & Means \pm SD \\
\hline Clearfil Mega Bond & $0.0470 \pm 0.0499^{\mathrm{a}}$ \\
\hline Prime \& Bond 2.1 & $0.0427 \pm 0.0839^{\mathrm{a}}$ \\
\hline Single Bond & $0.0314 \pm 0.0505^{\mathrm{a}}$ \\
\hline \hline
\end{tabular}

Values with the same letter were not significantly different by Tukey-Kramer test $(\mathrm{p}>0.05)$.

TABLE 3 - Means and standard deviations (SD) of dye concentration $(\mu \mathrm{g} / \mathrm{ml})$ for the adhesive systems used with previous acid etching.

\begin{tabular}{l|c}
\hline \multicolumn{1}{c|}{ Adhesive systems } & Means $\pm \mathrm{SD}$ \\
\hline Clearfil Mega Bond & $0.0928 \pm 0.0801^{\mathrm{a}}$ \\
\hline Prime \& Bond 2.1 & $0.0756 \pm 0.1021^{\mathrm{a}}$ \\
\hline Single Bond & $0.0073 \pm 0.0085^{\mathrm{b}}$ \\
\hline \hline
\end{tabular}

Values with the same letter were not significantly different by Tukey-Kramer test ( $\mathrm{p}>0.05)$.

Single Bond presented a better performance, showing lower microleakage means than Prime \& Bond 2.1 and Clearfil Mega Bond. No differences were detected when microleakage means were compared for each material used with and without previous acid etching.

\section{DISCUSSION}

The clinical performance of adhesive restorations is affected by other covariables besides dental materials that are unique in the oral environment such as the substrate the restorations are bonded to. The bonding of hydrophobic materials such as adhesive systems to a mineralized tissue with little water and few organic components, like the enamel, is relatively easy to perform and yields early clinical success, with no evidence of microleakage $e^{2,7,23,25}$. However, the dentinal substrate morphology is more complex. It is directly related to the pulp by dentinal tubules ${ }^{18}$. Dentin composition is based on water and organic components. This complex tissue challenges us to develop adhesive systems that can seal the interface tooth/ restoration in vivo.

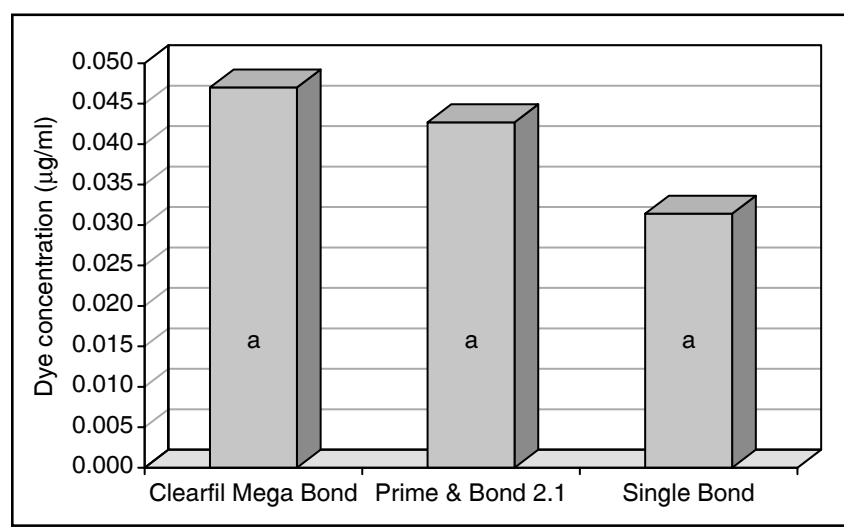

GRAPH 1 - Comparison between means of dye concentration for the adhesive systems without previous etching. Same letters represent no significant difference by Tukey-Kramer test.

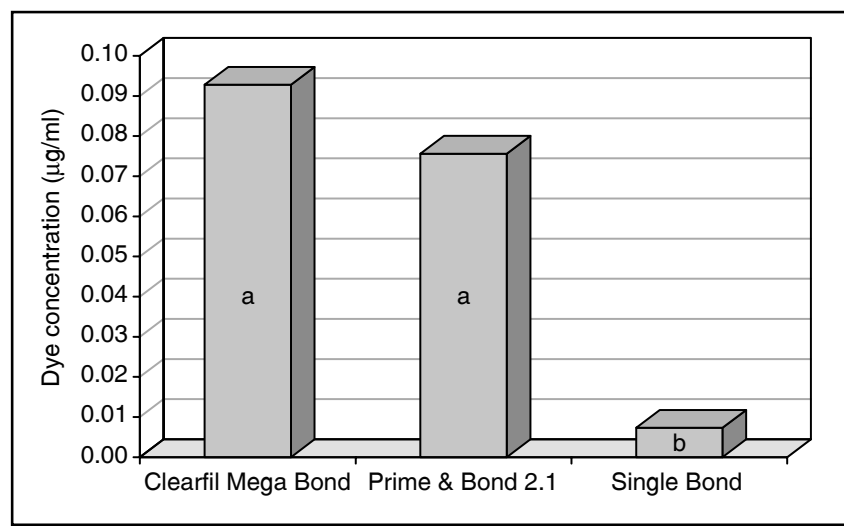

GRAPH 2 - Comparison between means of dye concentration for the adhesive systems with previous etching. Same letters represent no significant difference by Tukey-Kramer test.

The restoration margins of this study were located in root dentin, because the adhesion of adhesive systems to dentin needs to be improved and the quantitative evaluation of microleakage needs a standard substrate. For these reasons, restorations were made $4 \mathrm{~mm}$ below the cemento-enamel junction on the root surface of premolars.

The quantitative microleakage evaluation method was developed by Douglas, Zakariasen ${ }^{5}$ (1981). This methodology eliminates the subjective operator evaluation that is used in qualitative evaluations and measures all the infiltrated dye $^{9,10,15}$. The qualitative method does not allow us to take into account the variations of dye penetration pointed out from one zone to another of the restoration/tooth interface ${ }^{4}$. 
França FMG, Aguiar FHB, Santos AJS, Lovadino JR. Quantitative evaluation of microleakage in class V cavities using one-bottle and self-etching adhesive systems. Braz Oral Res 2004;18(3):253-9.

The one-bottle adhesive systems used in this study completely remove the smear layer by etching the dentin with $37 \%$ phosphoric acid and for optimal hybrid layer formation the manufacturers recommend a moist dentin surface ${ }^{12}$. However, there are differences in the composition: Single Bond uses water and alcohol solvent with HEMA and BisGMA monomers. Prime \& Bond 2.1 uses an acetone solvent with PENTA as the primary bonding promoter.

Clearfil Mega Bond (Kuraray Co.), a self-etching adhesive system, dissolves and incorporates the smear layer into the mixture, as it demineralizes dentin and encapsulates the collagen fibers and hydroxyapatite crystals ${ }^{7}$.

Single Bond presented the best performance when compared to the other adhesive systems, having the lowest microleakage values when used with previous etching. Our results are supported by Torres, Araujo ${ }^{26}$ (2000), who reported a reduced microleakage value of Single Bond compared to the self-etching adhesive system Clearfil Liner Bond II. This satisfactory performance might be related to the homogeneous hybrid layer formed by this system, as shown in a study performed by Prati et al. ${ }^{22}$ (1998). According to this study, Single Bond presented the most homogeneous hybrid layer, 1.5 to $2.5 \mu \mathrm{m}$ thick in peritubular dentin and 4.0 to $6.0 \mu \mathrm{m}$ thick in intertubular dentin. Similar values were also reported by Ferrari et al. ${ }^{6}$ (1997), where a hybrid layer 2 to $7 \mu \mathrm{m}$ thick was found for Single Bond adhesive system. No statistically significant differences in the degree of microleakage were noticed by Pilo, Bem-Amar ${ }^{21}$ (1999) when comparing multistep and one-bottle adhesive systems. Castelnuovo et al. $^{3}$ (1996) reported that one-bottle adhesives showed lower microleakage in cementum margins compared to their multistep versions.

The utilization of a brief etching time (15 seconds) and the adhesive application in a moist dentin environment can explain the good results of Single Bond ${ }^{19}$. The low microleakage means reported following wet bonding may be attributed to the fact that the demineralized dentin collagen does not collapse when kept wet; as opposed to what happens when it is dried with air blast. Moist dentin keeps the porous collagen network, which permits greater infiltration of adhesive monomers than the air-dried dentin surface with collapsed collagen ${ }^{19,20,28}$.

It is known that dentin dehydration increases the contact angle between the adhesive system and dentin, decreasing the surface wettability and making the adhesive infiltration difficult ${ }^{24}$. Acid etching the dentin with highly concentrated acid gels for a short time results in the successful removal of the smear layer ${ }^{11}$. The lowest microleakage means were found using Single Bond with previous acid etching, although differences were not significant.

The present results found for Prime \& Bond 2.1 were not expected for a one-bottle system that removes the smear layer to form a hybrid layer. It showed statistically significant higher microleakage means than Single Bond, and was statistically similar to the self-etching adhesive Clearfil Mega Bond. Barkmeier et al. ${ }^{1}$ (1999) reported that in their study the acid etching of dentin did not improve the bond strength values for Prime $\&$ Bond 2.1. The authors state that this system has shown the ability to bond to unetched dry dentinal surfaces. The monomer PENTA, which has a low $\mathrm{pH}$, acts as a self-etching agent when in contact with the dentin surface. The idea of self-etching adhesives is attractive because theoretically they can minimize the potential for voids or discrepancy between the mineralized surface and the adhesive penetration. However, when dentin is previously acid etched, self-etching adhesives systems may not infiltrate into all demineralized dentin, leaving gaps that could favor microleakage.

Kälin et al. ${ }^{11}$ in 1998, using low temperature scanning electron microscopy, showed that the dentin surface appeared to be partially covered with liquid and demonstrated "lake-like" areas of the adhesive Prime $\&$ Bond 2.1 after the application of the first layer. At higher magnification, the adhesive showed only superficial penetration into the collagen network. After the application of a second layer, the dentin was covered with a thin layer of adhesive. According to the authors, the "lake-like" areas observed after application of the first layer of Prime \& Bond 2.1 may be attributed to the pronounced collapse of the collagen network. Another explanation for this phenomenon could be that acetone-diluted adhesives contain insufficient resin to cover the whole surface area in one coat.

Prati et al. ${ }^{22}$ (1998) described the presence of a visible but extremely thin hybrid layer in superficial dentin and much thicker in deeper dentin for Prime $\&$ Bond 2.1 used with previous dentin conditioning. The acidic $\mathrm{pH}$ of Prime $\&$ Bond 2.1, the presence of a nonhomogeneous hybrid layer shown by this adhesive and the incomplete monomer infiltration in the demineralized collagen net- 
França FMG, Aguiar FHB, Santos AJS, Lovadino JR. Quantitative evaluation of microleakage in class V cavities using one-bottle and self-etching adhesive systems. Braz Oral Res 2004;18(3):253-9.

work may explain the adverse performance of this adhesive system in this study.

The adhesive system Clearfil Mega Bond acts simplifying clinical adhesive procedures by combining the acid etching of dentin with the priming step $^{7}$. The acidic part of the primer is neutralized at some point by calcium and phosphate ions released during demineralization. Demineralization is therefore self limiting, since the high concentration of these ions tends to limit further dissolution of apatite ${ }^{8}$. In self-etching adhesive systems, the primer is not rinsed off after its application. Therefore, the adhesive should be gently air dried after its application to allow the evaporation of the primer's solvent and avoid undesirable effects on the polymerization of the bonding agent applied after the dentin priming step ${ }^{16}$. These factors might be the reason for the little microleakage presented by Clearfil Mega Bond when the manufacturer's instructions were followed. The mean values found were not statistically different from Single Bond used with previous etching. The lowest microleakage means were found using no etching agent before the application of Clearfil Mega Bond, although differences were not significant.

\section{REFERENCES}

1. Barkmeier WW, Hammesfahr PD, Latta MA. Bond strength of composite to enamel and dentin using Prime $\&$ Bond 2.1 . Oper Dent 1999;24:51-6.

2. Barkmeier WW, Los AS, Triolo PT Jr. Bond strengths and SEM evaluation of Clearfil Liner Bond 2. Am J Dent 1995;8(6):289-93.

3. Castelnuovo J, Tjan AHL, Liu P. Microleakage of multistep and simplified-step bonding systems. Am J Dent 1996;9(6):245-8.

4. Déjou J, Sindres V, Camps J. Influence of criteria on the results of in vitro evaluation of microleakage. Dent Mater 1996;12:342-9.

5. Douglas WH, Zakariasen KL. Volumetric assessment of apical leakage utilizing a spectrophotometric, dye-recovery method [abstract]. J Dent Res 1981;512.

6. Ferrari M, Goracci G, Garcia-Godoy F. Bonding mechanism of three "one-bottle" systems to conditioned and unconditioned enamel and dentin. Am J Dent 1997;10(5):22430.

7. Gordan VV, Vargas MA, Cobb DS, Denehy GE. Evaluation of acidic primers in microleakage of class 5 composite resin restorations. Oper Dent 1998;23:244-9.

8. Gordan VV, Vargas MA, Cobb DS, Denehy GE. Evaluation of adhesive systems using acidic primers. Am J Dent 1997;10(5):219-23.

9. Hasegawa T, Retief DH. Quantitative microleakage of some dentinal bonding restorative systems. Dent Mater 1993;9:114-7.

\section{CONCLUSIONS}

- No significant differences in microleakage values were found among the adhesive systems when no etching agent was used.

- Single Bond showed statistically lower microleakage means than Clearfil Mega Bond and Prime $\&$ Bond 2.1 when $37 \%$ phosphoric acid was used to acid etch the dentin.

- Single Bond and Clearfil Mega Bond adhesive systems presented the same behavior when the manufacturers' instructions were followed, the first used with previous etching and the latter with no etching.

\section{ACKNOWLEDGMENTS}

This study was supported by FAPESP, grant \#99/02925-2. The authors are indebted to the Department of Pharmacology, Anesthesiology and Therapeutics, School of Dentistry of Piracicaba, State University of Campinas for the use of laboratory equipment.

10. Hasegawa T, Retief DH, Russell CM, Denys FR. Shear bond strength and quantitative microleakage of a multipurpose dental adhesive system resin bonded to dentin. J Prosthet Dent 1995;73(5):432-8.

11. Kälin C, Paul SJ, Schärer P, Düggelin M, Mathys D, Guggenheim R. Evaluation of the interface between one-bottle bonding agents and dentin by cryopreparation and low-temperature scanning electron microscopy (LTSEM). A pilot study on perfused dentinal samples. J Dent 1998;26:511-20.

12. Kanca J III. Resin bonding to wet substrate. I: Bonding to dentin. Quintessence Int 1992;23(1):39-41.

13. Kidd EAM. Microleakage and relation to amalgam and composite restorations. Br Dent J 1976;141(16):305-10.

14. Lee HL, Orlowski JA, Scheidt GC, Lee JR. Effects of acid etchants on dentin. J Dent Res 1973;52(6):1228-33.

15. Mandras RS, Retief DH, Russell CM. Quantitative microleakage of six dentin bonding systems. Am J Dent 1993;6(3):119-22.

16. Miyazaki M, Hirohata N, Takagaki K, Onose H, Moore BK. Influence of self-etching primer drying time on enamel bond strength of resin composites. J Dent 1999;27:2037.

17. Nakabayashi N, Saimi Y. Bonding to intact dentin. J Dent Res 1996;75(9):1706-15.

18. Pashley DH. Clinical correlations of dentin structure and function. J Prosthet Dent 1991;66(6):777-81. 
França FMG, Aguiar FHB, Santos AJS, Lovadino JR. Quantitative evaluation of microleakage in class V cavities using one-bottle and self-etching adhesive systems. Braz Oral Res 2004;18(3):253-9.

19. Pashley DH, Ciucchi B, Sano H, Horner JA. Permeability of dentin to adhesive agents. Quintessence Int 1993;24(9):618-31.

20. Pashley DH, Sano H, Ciucchi B, Yoshiyama M, Carvalho RM. Adhesion testing of dentin bonding agents: a review. Dent Mater 1995;11:117-25.

21. Pilo R, Bem-Amar A. Comparison of microleakage for three one-bottle and three multiple-step dentin bonding agents. J Prosthet Dent 1999;82(2):209-13.

22. Prati C, Chersoni S, Mongiorgi R, Pashley DH. Resininfiltrated dentin layer formation of new bonding systems. Oper Dent 1998;23:185-94.

23. Retief DH. Effect of conditioning the enamel surface with phosphoric acid. J Dent Res 1973;52(2):333-41.

24. Rosales JI, Marshall GW, Marshall SJ, Watanabe LG, Toledano M, Cabrerizo MA, et al. Acid-etching and hydration influence on dentin roughness and wettability. J Dent Res 1999;78(9):1554-9.
25. Settembrini L, Gultz JP, Scherer W, Kaim JA. A singlecomponent bonding system microleakage study. Gen Dent 1997;45(4):341-3.

26. Torres CRG, Araújo MAM. Adesivos de quinta geração: condicionamento ácido total $\mathrm{x}$ "primers" autocondicionantes. J Bras Clín Estét Odontol 2000;4(20):52-60.

27. van Meerbeek B, Inokoshi S, Braem M, Lambrechts $\mathrm{P}$, Vanherle G. Morphological aspects of the resin-dentin interdiffusion zone with different dentin adhesive systems. J Dent Res 1992;71(8):1530-40.

28. van Meerbeek B, Perdigão J, Lambrechts P, Vanherle G. The clinical performance of adhesives. J Dent 1998;26(1):1-20.

29. Yap A, Stokes NA, Pearson GJ. An in vitro microleakage study of a new multi-purpose dental adhesive system. J Oral Rehabil 1996;23(5):302-8.

30. Yoshiyama M, Matsuo T, Ebisu S, Pashley D. Regional bond strengths of self-etching/self-priming adhesive systems. J Dent 1998;26:609-16.

Received for publication on Sep 03, 2003

Sent for alterations on Apr 14, 2004

Accepted for publication on Jun 01, 2004 